YEARBOOK

of ANTITRUST

and REGULATORY

STUDIES

www.yars.wz.uw.edu.pl
Peer-reviewed scientific periodical, focusing on legal and economic issues of antitrust and regulation. Creative Commons Attribution-No Derivative Works 3.0 Poland License.

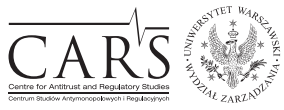

Centre for Antitrust and Regulatory Studies, University of Warsaw, Faculty of Management www.cars.wZ.uw.edu.pl

\title{
Intensity of Judicial Review of Fines in EU Competition Law
}

\author{
by
}

Krystyna Kowalik-Bańczyk*

\section{CONTENTS}

I. Introduction

II. Scope of unlimited jurisdiction

III. Intensity of control in case of unlimited jurisdiction

IV. Functioning of control in case of unlimited jurisdiction

V. Conclusions

\section{Abstract}

This article examines the scope of the activism of the General Court while exercising its so called unlimited jurisdiction in antitrust matters. It addresses three main questions: what is the exact scope of unlimited jurisdiction; what should the intensity of control in case of unlimited jurisdiction; and how does the functioning of control in case of unlimited jurisdiction looks in practice (how to readapt or recalculate the amount of fine and, if the court is prone to do this, how to replace the reasoning of the European Commission).

\section{Resumé}

Cet article examine l'étendue des activités du Tribunal de l'Union européenne dans le cadre de sa pleine juridiction en matière de droit de la concurrence. Il s'agit d'aborder trois questions principales: quel est la portée exacte de la pleine juridiction exercée par le Tribunal? Quelle devrait être l'intensité de son contrôle exercé dans le cadre de cette pleine juridiction? Et de quelle manière ce

* Krystyna Kowalik-Bańczyk is an Associate Professor at the Institute of Law Studies, Polish Academy of Sciences, LLM MES (Bruges), DEA (Toulouse). Since September 2016 she is a judge of the General Court of the European Union. ORCID: 0000-0001-7007-3203. Article received: 29 July 2019, accepted: 20 September 2019. 
contrôle fonctionne-t-il en pratique (comment réadapter ou recalculer le montant de l'amende et, le cas échéant, remplacer le raisonnement de la Commission européenne)?

Key words: unlimited jurisdiction; scope of judicial control; antitrust sanctions; ne ultra petita; measures of public order.

JEL: K21; K42

\section{Introduction}

Jurisdiction of the General Court of the European Union covers different domains and has a variable character. Considering the statistics ${ }^{1}$, the General Court is first and foremost an administrative court of the European Union, controlling, under Article 263 of the Treaty on the Functioning of the European Union (TFEU) ${ }^{2}$, the legality of acts issued by the institutions, organs and other bodies of the European Union. The usual scope of control consists in a legality control, where the General Court analyses the pleas raised by the parties as to the legality of the measure in question ${ }^{3}$. There are however,

${ }^{1} \mathrm{Cf}$ the numbers of cases indicated in the Annual Report of 2018 as brought for the General Court is 1009, out of which 44 concern competition, 79 concern state aids, 349 are direct actions in intellectual property matters and 311 are direct actions of all other kinds. Other types of actions are not falling into the category of administrative jurisdiction.

2 Treaty on the Functioning of the European Union, OJ C 202, 07.06.2016.

3 CJ judgment of 11 September 2014, Case C-67/13 P Groupement des cartes bancaires (CB) v European Commission, ECLI:EU:C:2014:2204, paras. 44-46: ' 44. (...) it is apparent from the EU case-law that, when an action is brought before it under Article 263 TFEU for the annulment of a decision applying Article 81(1) EC, the General Court must generally undertake, on the basis of the evidence adduced by the applicant in support of the pleas in law put forward, a full review of whether or not the conditions for applying that provision are met (see, to that effect, CJEU judgments: of 11 July 1985, Case 42/84 Remia and Others v Commission, ECLI:EU:C:1985:327, para. 34; of 8 December 2011, Case C-386/10 P Chalkor v Commission (ECLI:EU:C:2011:815), paras 54 and 62; and of 6 December 2012, Case C-199/11 Otis and Others, ECLI:EU:C:2012:684, para. 59). The General Court must also establish that the Commission has stated reasons for its decision (see, to that effect, judgments in Case C-386/10 P Chalkor v Commission, para. 61 and the case-law cited, and Case C-199/11 Otis and Others, para. 60). Para 45: "In carrying out such a review, the General Court cannot use the margin of assessment which the Commission enjoys by virtue of the role assigned to it in relation to competition policy by the EU and FEU Treaties, as a basis for dispensing with an in-depth review of the law and of the facts (see, to that effect, judgments in C-386/10 P Chalkor v Commission, para. 62, and Otis and Others, para. 61). 46. In particular, although the Commission has, in accordance with that role, a margin of assessment with regard to economic matters, in particular in the context of complex economic assessments, that does not mean, as is 
in this administrative jurisdiction, some cases of extended scope of control. Those specific cases cover: first, the control of decisions issued by the Board of Appeal of the Office of the Intellectual Property of the European Union (EUIPO), where the Court exercises a kind of 'broader' control ${ }^{4}$, and, second, the control of penalties imposed by the institutions of the European Union, where the General Court has the so-called unlimited jurisdiction (Article 261 TFEU). According to some (Giacobbo-Peyronnel and Perillo, 2017), the third type of cases of an extended jurisdiction has emerged as a result of the jurisprudence of the Court of Justice, namely the jurisprudence on civil service, where no legal basis exists for this broader jurisdiction but the Court pronounces itself on the pecuniary obligations ${ }^{5}$.

The notion of unlimited jurisdiction has not been defined in the treaties. Its origin gets back to French administrative law where the 'recours de pleine juridiction' is opposed to the narrower control of legality of administrative decisions $^{6}$.

Without unlimited jurisdiction being defined, it still appears in the Treaty on the Functioning of the European Union. The notion of unlimited jurisdiction is used in Article 261 TFEU, which provides: 'Regulations adopted jointly by the European Parliament and the Council, and by the Council, pursuant to the provisions of the Treaties, may give the Court of Justice of the European Union unlimited jurisdiction with regard to the penalties provided for in such

apparent from the preceding paragraph, that the General Court must refrain from reviewing the Commission's legal classification of information of an economic nature. Although the General Court must not substitute its own economic assessment for that of the Commission, which is institutionally responsible for making those assessments (see, to that effect, in particular, judgments: of 10 July 2008, Case C-413/06 P Bertelsmann and Sony Corporation of America v Impala (ECLI:EU:C:2008:392), para. 145, and of 24 January 2013, Case C-73/11 P Frucona Košice v Commission, ECLI:EU:C:2013:32, para. 89 and the case-law cited), it is apparent from now well-settled case-law that not only must the EU judicature establish, among other things, whether the evidence relied on is factually accurate, reliable and consistent but also whether that evidence contains all the relevant information which must be taken into account in order to assess a complex situation and whether it is capable of substantiating the conclusions drawn from it (see, to that effect, in particular, judgments in C-386/10 P Chalkor v Commission, para. 54 and the case-law cited, and Case C-199/11 Otis and Others, para. 59).'

4 Cf Art. 72, para. 3 of Regulation (EU) 2017/1001 and Art. 61, para 3 of Regulation (CE) 6/2002. But the scope of this review is interpreted in a very narrow way by the CJEU: judgment of 5 July 2011, Case C-263/09 P, Edwin/OHMI, ECLI:EU:C:2011:452, paras. 71 and 72 or judgment of 1 February 2018, Case T-265/17 ExpressVPN/EUIPO (EXPRESSVPN), ECLI:EU:C:2018:79.

5 ECJ judgement of 16 December 1960, Case 44/59 Fiddelaar v European Commission, Rec. 1077, 1093, ECLI:EU:C:1960:47; ECJ judgment of 5 June 1980, Case 24/79 Oberthür v European Commission, ECLI:EU:C:1981:207, paras 13 to 15.

${ }^{6}$ For a broad explanation cf Chapus, 2006. 
regulations ${ }^{7}$. When based on Article 261 TFEU, unlimited jurisdiction is exercised on the basis of the following provisions of EU Regulations:

- Article 5 of Regulation 2532/98 concerning the powers of the European Central Bank to impose sanctions

- Article 31 of Regulation $1 / 2003^{9}$ on the implementation of the rules on competition

- Article 16 of Regulation 139/200410 on the control of concentrations between undertakings

- Article 84 of Regulation 2018/113911 on common rules in the field of civil aviation and establishing a European Aviation Safety Agency

- Article 15 of Regulation 80/200912 on a Code of Conduct for computerised reservation systems.

The most prominent case of unlimited jurisdiction is provided in antitrust law (Bernardeau and Christienne, Brussels 2013; Vesterdorf, 2009; Arabardijev, 2012, p. 383-402; Jaeger, 2011; Bosco, 2014) ${ }^{13}$. There the judicial review comprises two very distinct aspects: review of legality and review of the amount of the fines imposed by the Commission. The implications for the General Court are very different, in terms mainly of its possible activism. It still remains an open question if the General Court is to be very active to use its unlimited jurisdiction. In particular, it is not clear if it is to use it towards the sanction only or towards the whole mental process leading to the imposition of a sanction - in

7 Similar provision is contained in Art. 144 of Euroatom Treaty, Treaty establishing the European Atomic Energy Community, OJ C 203, 07.06.2016.

8 Council Regulation (EC) No 2532/98 of 23 November 1998 concerning the powers of the European Central Bank to impose sanctions, OJ L 318, 27.11.1998, p. 4-7.

9 Council Regulation (EC) No 1/2003 of 16 December 2002 on the implementation of the rules on competition laid down in Articles 81 and 82 of the Treaty (Text with EEA relevance), OJ L 1, 04.01.2003, p. 1-25.

10 Council Regulation (EC) No 139/2004 of 20 January 2004 on the control of concentrations between undertakings (the EC Merger Regulation) (Text with EEA relevance), OJ L 24, 29.01.2004, p. 1-22.

11 Regulation (EU) 2018/1139 of the European Parliament and of the Council of 4 July 2018 on common rules in the field of civil aviation and establishing a European Union Aviation Safety Agency, and amending Regulations (EC) No 2111/2005, (EC) No 1008/2008, (EU) No 996/2010, (EU) No 376/2014 and Directives 2014/30/EU and 2014/53/EU of the European Parliament and of the Council, and repealing Regulations (EC) No 552/2004 and (EC) No 216/2008 of the European Parliament and of the Council and Council Regulation (EEC) No 3922/91 (Text with EEA relevance.), OJ L 212, 22.08.2018, p. 1-122.

12 Regulation (EC) No 80/2009 of the European Parliament and of the Council of 14 January 2009 on a Code of Conduct for computerized reservation systems and repealing Council Regulation (EEC) No 2299/89 (Text with EEA relevance), OJ L 35, 04.02.2009, p. 47-55

13 It might be explained by the level of fines imposed. In 2017 Google was imposed a landmark $€ 4.34$ billion fine, In 2014 the highest fine was of $€ 1.69$ billion, in $2013 € 1.88$ billion, in $2012-€ 1.88$ billion, in $2011-€ 614$ million, in $2010-€ 2.87$ billion. 
the second scenario would it not be held to be 'over-active' and trespass the limits of its action imposed by the will of the parties? In principle, unlimited jurisdiction implies a transfer of powers, because the General Court replaces the Commission in its reasoning. It can 'step in the shoes' of the Commission in many different respects. The General Court can rely on new evidence and rely on facts post-dating the decision ${ }^{14}$. Despite those precisions, confirmed by the jurisprudence as to the scope of the activism of the General Court while exercising its unlimited jurisdiction, there are at least three questions that still raise doubts and will be addressed by this text: 1) what is the exact scope of unlimited jurisdiction; 2) what is the intensity of control in case of unlimited jurisdiction; and 3) what is the functioning of control in case of unlimited jurisdiction (how to readapt or recalculate the amount of fine and, is the court prone to do this, replacing the reasoning of the European Commission).

14 This is in contrast with the jurisprudence existing in other domains than antitrust. For instance, for trade mark litigation: judgment of 13 March 2007, C-29/05 P OHMI v Kaul, ECLI:EU:C:2007:162, paras. 53 to 54: '53. It follows, in particular, from that provision that the Court of First Instance may annul or alter a decision against which an action has been brought only if, at the time the decision was adopted, it was vitiated by one of those grounds for annulment or alteration. The Court of First Instance may not annul or alter that decision on grounds which come into existence subsequent to its adoption (Case C-416/04 P Sunrider v OHIM [2006] ECR I-4237, paragraphs 54 and 55). 54. It is also apparent from that provision that, as found by the Court of First Instance in a correct and consistent manner, facts not submitted by the parties before the departments of OHIM cannot be submitted at the stage of the appeal brought before that Community court. The Court of First Instance is called upon to assess the legality of the decision of the Board of Appeal by reviewing the application of Community law made by that board, particularly in the light of facts which were submitted to the latter (see, to that effect, Case C-214/05 P Rossi v OHIM [2006] ECR I-7057, paragraph 50). By contrast, that Court cannot carry out such a review by taking into account matters of fact newly produced before it." But in competition law the position of the Court is more open: cf judgment of 1 July 2010, Knauf Gips c. v Commission, C-407/08 P, points 89 to 91: 89. In that regard, as the appellant correctly argues as regards the application of Articles $81 \mathrm{EC}$ and $82 \mathrm{EC}$, there is no requirement under the law of the European Union that the addressee of the statement of objections must challenge its various matters of fact or law during the administrative procedure, if it is not to be barred from doing so later at the stage of judicial proceedings. 90. Although an undertaking's express or implicit acknowledgement of matters of fact or of law during the administrative procedure before the Commission may constitute additional evidence when determining whether an action is well founded, it cannot restrict the actual exercise of a natural or legal person's right to bring proceedings before the General Court under the fourth paragraph of Article 263 TFEU. 91. In the absence of a specific legal basis, such a restriction is contrary to the fundamental principles of the rule of law and of respect for the rights of the defence. Moreover, the rights to an effective remedy and of access to an impartial tribunal are guaranteed by Article 47 of the Charter of Fundamental Rights of the European Union which, under the first subparagraph of Article 6(1) TEU, has the same legal value as the Treaties. Under Article 52(1) of that charter, any limitation on the exercise of the rights and freedoms recognized by the charter must be provided for by law.' 
Before dwelling on those three questions, one has to contrast the scope of this control with the requirements of the European Court of Human Rights on due process and access to court. In cases where penalties are imposed, there is a necessity to compare the notion of unlimited jurisdiction (existing in EU law) with the notion of full jurisdiction, used by the ECtHR. In the jurisprudence of the ECtHR, in order to guarantee full access to justice in cases where penalties are imposed by administrative bodies different than the courts ${ }^{15}$, there is a requirement that such decisions should be subject to review by a court having 'full jurisdiction' 16 . In this context, it is not enough that the court in question has jurisdiction to judge the merits of the case ${ }^{17}$. Control limited to checking the margin of appreciation is not corresponding to this requirement either ${ }^{18}$. Full jurisdiction means that the court should be able to adjudicate fully both on questions of facts and of law. If it cannot assess the circumstances of the imposition of the sanction in question, or to assess its proportionality, there is no full jurisdiction in place ${ }^{19}$.

This initial position of the ECtHR seemed not very favorable for the level of control exercised by the General Court. It has however been nuanced because of the administrative character of the matter in question ${ }^{20}$. The ECtHR admits that administrative courts have limited jurisdiction as to the assessment of facts stated by the administrative organs. If an administrative decision is issued by an administrative organ in 'quasi-judicial' proceedings, with guarantees stemming from Article $6 \mathrm{ECHR}$, then a limited jurisdiction of the court should be accepted ${ }^{21}$, unless the matter in question is in fact a criminal matter ${ }^{22}$. The court exercising full jurisdiction has, according to the ECtHR, the right to change all statements, both as to the facts and to the law, upon which the administrative organ adjudicated, if they are covered by the pleas of the parties. In the Menarini case (Bombois, 2011) ${ }^{23}$, the ECtHR has indirectly confirmed

15 In EU law there is no problem with the fact that it is the Commission and not the Court that is imposing a sanction, cf judgment of 18 July 2013, Case C-501/11 P Schindler Holding Ltd and Others v European Commission, ECLI:EU:C:2013:522.

16 Schmautzer v Austria, app no 15523/89, para 36; Kyprianou v Cyprus, paras. 43-46.

17 Le Compte, Van Leuven and De Meyere, app no 6878/75; 7238/75, para. 51; Zumtobel v Austria, app no 12235/86, para. 29; Umlauft v Austria, app no 15527/89, para. 37; Van Kück v Germany, app no 35968/97, para. 48; Beneficia Cappella Paolini v San Marino, app no 40786/98, paras. 28-29.

18 Obermeier v Austria, app no 11761/85, para. 70.

19 Le Compte, Van Leuven and De Meyere, app no 6878/75, 7238/75, para. 51; Silevester's Horeca Service v Belgium, app no 47650/99, para. 28.

${ }^{20}$ Potocka $v$ Poland, app no 33776/96, paras. 52-59.

21 Bryan v UK, app no 19178/91, paras. 45-47; Potocka v Poland, app no 33776/96, para. 53; Menarini Diagnostics S.R.L. v Italy, app no 43509/08, para. 59.

${ }^{22}$ Schmautzer v Austria, app no 15523/89, para. 36.

23 Menarini Diagnostics S.R.L. v Italy, app no 43509/08, para. 67. 
that the level of control exercised by the General Court as to the penalties imposed by the European Commission is in line with the requirements of Article 6 ECHR.

\section{Scope of unlimited jurisdiction}

Unlimited jurisdiction is, by definition, limited as to its scope, as it only concerns the imposition of financial sanctions that, with some reservations, might be compared to penal sanctions ${ }^{24}$. However, there are at least two further reasons to consider that the notion of unlimited jurisdiction is, in fact, quite limited.

The first reason concerns the lack of autonomy of unlimited jurisdiction. Usually applicants claim to control the legality of decisions ${ }^{25}$ and, at the same time, ask for the exercise of unlimited jurisdiction as to the sanctions imposed by such decisions. This raises the question whether Article 261 constitutes a separate legal basis for judicial control or if it can be used autonomously. According to CJEU, there is a link between Article 263 (control of legality) and Article 261, and this second provision is only additional, extending the jurisdiction of EU judges. According to case-law, there is no autonomous, separate legal basis to introduce a direct action under Article 261 TFEU (Barbier de la Serre, 2015, p. 76-77) ${ }^{26}$. If there is no autonomous action to invite the Court to adjudicate upon sanctions under Article 261 TFEU, the control is always linked with the legality control, exercised towards a decision that has been put in question under Article 263 TFEU. Unlimited jurisdiction can only be exercised if there is a proceeding under Article 263 TFEU. Still, once the proceeding is open under Article 263 TFEU, unlimited jurisdiction can be exercised by the Court even if no illegality is stated ${ }^{27}$ (Clausen, 2018,

${ }^{24}$ Cf judgment of 10 April 2014, Cases C-231/11 P to C-233/11 P Commission v Siemens Osterreich, ECLI:EU:C:2014:256, para. 75, where it is stated that the competence of the Court under unlimited jurisdiction covers only the questions of sanctions.

25 The usual judicial control of decisions issued by the institutions, bodies and offices of the UE (mainly: the European Commission) looks like the classic control of administrative decisions exercised by administrative courts. According to Art. 263 TFEU, there are four reasons for annulling an act: 1) lack of competence, 2) infringement of an essential procedural requirement, 3 ) infringement of the Treaties or of any rule of law relating to their application, or 4) misuse of powers.

26 Order of 9 November 2004, Case T-252/03 FNICGV v European Commission, ECLI:EU:T:2004:326, para. 22.

27 Cf judgment of 15 October 2002, Case C-238/99 P Limburgse Vinyl Maatschappij $v$ European Commission, ECLI:EU:C:2002:582, para. 692; judgment of 3 September 2009, Case 
Bruylant, p. 343, 344-345 ; Wahl, 2015, p. 727-740; Expert and Poullet, 2017, p. 545-592). This possibility of using Article 261 even if the decision on the merits seems legal has been confirmed by EU Courts ${ }^{28}$.

When claims based on Article 261 are introduced together with the pleading on the legality of the measure in question, this raises the question of the scope of jurisdiction of the General Court on the pleas raised and the level of sanctions ${ }^{29}$. The General Court can, under Article 261 TFEU, control every infringement leading to a sanction and every sanction itself ${ }^{30}$. It can: annul the sanction as such ${ }^{31}$, it can even increase the sanction despite the plea ${ }^{32}$, or it can follow the suggestions of the Commission to increase the sanction ${ }^{33}$. According to some judgments, the control exercised by the Court under Article 261 TFEU can cover the infringement of the law, equity and the statement of facts. But in principle, the exercised control should be used mainly to verify if the principle of proportionality has not been infringed $^{34}$.

The second reason for stating that unlimited jurisdiction has its limitations is linked with the scope of the control exercised by the Court in the context of double legal basis for introducing the action in front of the General Court. If the control of Article 261 is always accompanied by the control of legality under 263 , there might be a doubt if unlimited jurisdiction only covers the setting of the fine or the whole decision. In addition to the doubts of this control, in some areas, such as competition law or commercial policy, EU institutions

C-534/07 P Prym et Prym Consumer v European Commission, ECLI:EU:C:2009:505, para. 89.

28 Judgment of 8 February 2007, Case C-3/06 P, Groupe Danone v European Commission, ECLI:EU:C:2007:88, paras. 53-54, 60-61; jugdment of 8 July 2008, Case T-53/03 BPB v European Commission (Plasterboard), ECLI:EU:T:2008:254, paras. 478-483; judgment of 8 July 2008, Case T-54/03, Lafarge v European Commission (Plasterboard), ECLI:EU:T:2008:255, para. 775; judgement of 6 May 2009, Case T-122/04 Outokumpu and Luvata v European Commission (Copper Industrial Tubes), ECLI:EU:T:2009:141, para. 66; jugment of 6 May 2009, Case T-127/04, KME Germany v European Commission, ECLI:EU:T:2009:142, para. 121; judgment of 19 May 2010, Case T-21/05 Chalkor v European Commission, ECLI:EU:T:2010:205, para. 113.

29 Judgment of 8 October 2008, Case T-69/04, Schunk $v$ European Commission, ECLI:EU:T:2008:415, para. 246.

30 Judgment of 3 March 2011, Cases T-117/07 and T-121/07 Areva v European Commission, ECR 2011 II-00633, para. 227.

31 Judgment of 8 February 2007, Case C-3/06 P Groupe Danone v European Commission, ECLI:EU:C:2007:88, para. 61; judgment of 30 September 2009, Case T-161/05 Hoechst GmbH v European Commission, ECLI:EU:T:2009:366, para. 101.

32 Judgment of 8 February 2007, Case C-3/06 P Groupe Danone v European Commission, ECLI:EU:C:2007:88, paras. 61-62; judgment of 14 May 1998, Case T-348/94 Enso Espanola, ECLI:EU:T:1998:102.

33 Case T-69/04 Schunk v European Commission, para. 245.

34 Case T-348/94 Enso Espanola, para. 64. 
enjoy a broad discretion by reason of the complexity of the economic, political and legal situations which they have to examine ${ }^{35}$. In those cases, judicial review (of legality) must sometimes be limited to verifying whether relevant procedural rules have been complied with, whether the facts on which the contested choice is based have been accurately stated, and whether there has been manifest error ${ }^{36}$ in the appraisal of those facts or misuse of powers ${ }^{37}$. However, even in cases where the organ issuing a decision in question has a large margin of discretion with regard to complex economic matters, the General Court is not to refrain from reviewing the interpretation of information of an economic nature. The EU judicature must, among other things, not only establish whether the evidence put forward is factually accurate, reliable and consistent, but must also determine whether that evidence contains all the relevant data that must be taken into consideration in appraising a complex situation, and whether it is capable of substantiating the conclusions drawn from it ${ }^{38}$.

In order to define the scope of judicial control under Article 261 TFEU, one has to determine whether the control should cover the elements of the sanction only, or the totality of elements exposed in the decision in question. Should it be this first scenario, eventual elements of the sanction could be those that influence the level of the sanction: gravity, duration, mitigating as well as all possible aggravating circumstances. In the case of the second scenario, the elements of the decision - the legal qualification or assessment of the infringement in question should also be controlled.

Constructing Article 263 TFEU, the Court of Justice stated, in C-295/12 P Telefónica et Telefónica de España v. Commission'39 that: '53. (...) it is established case-law that the review of legality provided for in Article 263 TFEU involves review by the European Union judicature, in respect of both the law and the facts, of the arguments relied on by applicants against the contested decision, which means that it has the power to assess the evidence, annul

35 Judgment of 11 February 2010, Case C-373/08 Hoesch Metals and Alloys, ECLI:EU:C:2010:68, para. 61.

36 This notion of itself raises much critique: according to Craig, 2012: 'the repeated articulation of manifest error conceals more than it reveals', which could be interpreted in a way that sometimes there is human will to control something and sometimes not. In a similar vein, according to Castillo de la Torre and Fournier, 2017 (p. 301): 'manifest is whatever the judges consider to be manifest'.

37 Judgment of 11 February 2010, Case C-373/08 Hoesch Metals and Alloys, ECLI:EU:C:2010:68, para. 62.

38 Case C-199/11 Otis and Others v European Commission, para. 59; judgment of 15 February 2005, Case C-341/05 Commission v Tetra Laval, ECLI:EU:C:2005:88, para. 39; judgment of 19 May 2010, Case T-21/05 Chalkor v European Commission, ECLI:EU:T:2010:205, para. 54.

39 Judgment of 10 July 2014, C-295/12 P Telefonica et Telefonica de España, ECLI:EU:C:2014:2062. 
the decision [and - but I will keep it aside for now] - to alter the amount of the fine $e^{40}$.

In two relatively recent cases: C-389/10 P KME Germany v Commission and C-603/13 P Galp Energia España (Martinez-Lage, 2016, p. 608-610; Nikolic, 2012, p. 583-588), the Court of Justice made it clear that unlimited jurisdiction only covers the setting of the fine and not the whole assessment of the circumstances leading to the decision in question. The opinion of the Court of Justice expressed in KME and Galp Energa ${ }^{41}$ seems to clearly state that only the sanction as such should be considered. In the case T-455/14 of 18 July 2018 Pirelli \&C v European Commission, the General Court stated that it can not only change the level of the fine but also diversify the ways of payment and the whole discussion on the imposition of the fine ${ }^{42}$.

Even if only the sanction is to be covered by unlimited jurisdiction, several issues remain unclear as to the scope of the exercised control. How and if should the Court consider the level of the sanction, its gravity, its duration, as well as its mitigating and aggravating circumstances? Should it take into consideration the fact that we face one or a series of infringements? Should it always be linked with the annulment of the decision in question? In Prym, the Court expressed an opinion that unlimited jurisdiction allows the Court to vary the measure without even annulling the decision - by taking into account all of the factual circumstances. In cases like Arkema France or Telefonica, the Commission was not active to question such factual circumstances, so the Court of Justice stated that it is not for the Court to fill this gap. The Court might be replacing the Commission in its reasoning as for the construction of the sanction, but it cannot replace its actions or omissions. Therefore, unlimited jurisdiction cannot be perceived as a case of a complete transfer of powers from the European Commission to the General Court. On the other hand, there is no prohibition of reformationis in peius, that we will address broader below. However, this lack of formal prohibition should not be an indication that any increase in the fine should be possible. If unlimited jurisdiction is to be perceived in light of its objectives, which include the protective function of this jurisdiction (Clausen, 2018, p. 351), a too broad interpretation of the notion of unlimited jurisdiction might introduce an element of insecurity to the parties of the proceeding taking place in front of the General Court.

${ }^{40}$ Cf judgment of 18 July 2013, Case C-501/11 P Schindler Holding Ltd and Others $v$ European Commission, ECLI:EU:C:2013:522, para. 38.

41 Judgment of 16 January 2016, Case C-603/13 P Galp Energia Espana v European Commission, ECLI:EU:C:2016:38, para. 76; judgment of 6 May 2009, Case T-127/04 KME Germany v European Commission, ECLI:EU:T:2009:142, para. 120.

42 Judgment of 18 July 2018, Case T-455/14 Pirelli \&C v European Commission, ECLI:EU:T:2018:450, para. 147. 


\section{Intensity of control in case of unlimited jurisdiction}

The issue of the scope of unlimited jurisdiction can also be analysed from the perspective of the question 'how far can the Court go'. Thus, the first issue that needs to be clarified is whether the exercise of unlimited jurisdiction can occur only within the plea or can it be exercised by the Court ex officio. This second possibility - that the Court raises the issues of unlimited jurisdiction ex officio - should be admissible only if we consider that it forms an element of the public order ${ }^{43}$. This is a very delicate question, followed by other doubts: is the question of proportionality of the fine a question of public order ${ }^{44}$ ? Should there be a special justification for the gravity of the sanction in this respect or otherwise would the Court be free to impose its vision on the parties, regardless of their opinions? It seems that as the very notion of unlimited jurisdiction is an exception to judicial deference, the additional referral to measures of public policy (or order) should be avoided (Clausen, 2018, p. 382). If we exclude the possibility of using unlimited jurisdiction ex officio, that would limit the court to only follow the critique expressed in this respect in the particular pleas, in a given case. So the only 'initialising factor' would be a plea, and the court can only act if it is asked, unless we admit that there might be a public order argument, in favour of broader competences for the court. Some authors are of the opinion that any control of fines could not be a control led ex officio (Clausen, 2018, p. 375) ${ }^{45}$. They draw this conclusion from the recent judgments of the Court of Justice ${ }^{46}$, where it was stated: 'Ensuite, il résulte d'une jurisprudence constante de la Cour que la procédure suivie devant les juridictions de l'Union est contradictoire. À l'exception des moyens d'ordre public, que le juge est tenu de soulever d'office, telle l'absence de motivation de la décision attaquée, c'est à la partie requérante qu'il appartient de soulever des moyens contre cette dernière et d'apporter des éléments de

43 Some authors argue that it seems confirmed by the following judgments: judgment of 8 December 2011, C-386/10 P Chalkor v European Commission, paras. 64 and 70; judgment of 8 December 2011, C-389/10 P KME Germany v European Commission, para. 131; judgment of 6 May 2009, Case T-127/04 KME Germany v European Commission, ECLI:EU:T:2009:142, para. 104. Cf Clausen, 2018, p. 336.

${ }^{44} \mathrm{Cf}$ conclusions of Advocate General Bot of 22 November 2012, Case C-89/11 E.ON Energie v European Commission, para. 115.

45 This author considers that the jurisprudence on this issue has fallen into desuetude.

46 Judgment of 16 February 2017, Case C-90/15 P Hansen \& Rosenthal et H\&R Wax Company Vertrieb v European Commission, ECLI:EU:C:2017:123, para. 25; judgment of 16 February 2017, Case C-94/15 P Tudapetrol Mineralölerzeugnisse Nils Hanssen v European Commission, ECLI:EU:C:2017:124, para. 22; judgment of 16 February 2017, Case C-95/15 P H\&R ChemPharm v European Commission, ECLI:EU:C:2017:125, para. 86. 
preuve à l'appui de ces moyens ${ }^{37}$. The only exception to this position could be, according to the same author, a situation where the Court states an illegality and raises it ex officio as a public policy measure (Clausen, 2018, p. 375). Still, those 'public policy measures' seem to be a 'ghost' or an 'empty shell' without any content, because they have never been invoked in a concrete case in the jurisprudence of the General Court (Clausen, 2018, p. 379) ${ }^{48}$. The only possible measure of public order seems a possible obligation to align (but only in a positive way) the fines of mother and daughter companies. On the other hand, the assessment of a fine by the Court is not excluded in case of the legality of the decision. The jurisprudence has admitted such examples, where the pleas based on illegality were rejected, and the fine was still subject to reassessment of the Court ${ }^{49}$. It is, however, subject to the free choice of the Court whether to exercise this control, and in this sense, it is different from the ex officio application of public policy measures (which are obligatory in nature, once the Court states the existence of such a measure) (Clausen, 2018, p. 399). In any case, the use of unlimited jurisdiction in favor of one of the parties should not constitute a problem (Barbier de la Serre, 2007, p. 85; Clausen, 2018, Bruylant, p. 403-404 $)^{50}$. It is rather the possibility to increase the sanction that causes some concerns as to the principle ne ultra petita. In particular, the Court should not change the fine imposed on third parties to

47 Judgment of 24 October 2013, Case C-510/11 P Kone e.a. v European Commission, ECLI:EU:C:2013:696, para. 30.

48 F. Clausen, Les moyens d'ordre public devant la Cour de justice de l'Union européenne, Bruxelles 2018, Bruylant, p. 379. This author gives an example of the Tomkins jurisprudence - judgment of 22 January 2013, Case C-286/11 P Commission v Tomkins, ECLI:EU:C:2013:29, paras. 43-45, 49-50, where the Court of Justice stated that the General Court can, even ex officio, benefit the mother company with a reduction of the fine imposed on it if its daughter company has profited of such a reduction. Cf also: judgment of 17 September 2015, Case C-597/13 P Total v European Commission, ECLI:EU:C:2015:613, para. 41; judgment of 27 April 2017, Case C-516/15 P Akzo Nobel v European Commission, ECLI:EU:C:2017:314, para. 62.

49 For instance, the Court was stating that the level of fine is 'appropriate', 'adequate': judgment of 14 February 1972, Case 48/69 ICI v Commission, ECLI:EU:C:1972:70, para. 147; judgment of 14 July 1972, Case 49/69 BASF, ECLI:EU:C:1972:71, para. 38; judgment of 14 July 1972, Case 51/69 Bayer AG v European Commission, ECLI:EU:C:1972:72, para. 42; judgment of 14 July 1972, Case 52/69 Geigy v European Commission, ECLI:EU:C:1972:73, para. 53; or for the General Court: judgment of 17 December 2003, Case T-219/99 British Airways v European Commission, ECLI:EU:T:2003:343, para. 316. Cf Clausen, 2018, p. 397.

50 Jugdment of 10 December 1957, Case 8/56 ALMA v Haute Autorité, ECLI:EU:C:1957:12; judgment of 1 April 1993, Case T-65/89 BPB Industries et British Gypsum v European Commission, ECLI:EU:T:1993:31, para. 162; judgment of 10 July 2010, Case T-321/05 AstraZeneca v European Commission, ECLI:EU:T:2010:266, para. 884; judgment of 12 July 2001, Cases T-202/98, T-204/98, T-207/98 Tate\&Lyle v European Commission, ECLI:EU:T:2001:185, paras. 22, $163-164$. 
the litigation in front of $i^{51}$, if the fine is to be increased ${ }^{52}$. There is, however, a number of examples where the Court was using its unlimited jurisdiction only after having been asked to do this by a separate plea ${ }^{53}$.

This contrasts strongly with different jurisprudence where the possibility to increase the sanction, even on the own motion of the Court, was admitted (Clausen, 2018, p. 407) ${ }^{54}$. In this respect, it seems that the principle of interdiction of reformation in peius is not fully operational. Despite the fact that the objective of unlimited jurisdiction is, inter alia, the effective judicial protection of undertakings concerned, it has to be balanced with the objective of EU antitrust law that covers also the protection of consumers (Clausen, 2018, p. 408) $)^{55}$. If, for instance, nobody noticed that the fine imposed does not stay within the limits set in Article 23(2) second and third subparagraphs of Regulation no $1 / 2003$, should this type of error be considered as a question of illegality. It seems that probably it should, with all the consequences for unlimited jurisdiction like, for instance, whether it is a question of control of proportionality. Probably, proportionality control would be instigated by the Court on its own motion, because it seems that proportionality is not a question of public order. In latest jurisprudence, the importance of the principle of contradictoire is particularly visible, and this implies that the Court should not use its unlimited jurisdiction ex officio ${ }^{56}$.

51 Judgment of 10 April 2014, Cases C-231/11 P to C-233/11 P Commission v Siemens Österreich, ECLI:EU:C:2014:256, paras. 126-130. In this case, the Court, having changed the fine imposed solidarily on three companies, of which only two instigated the proceeding, has acted ultra petita (Clausen, 2018, p. 405).

52 The opposite situation - reduction of the fine in favor of a third party to the proceeding, seems admissible in the jurisprudence: judgment of 9 September 2015, Case T-82/13 Panasonic and MT Picture Display v European Commission, ECLI:EU:T:2015:612, para. 1 of sentence; judgment of 24 June 2015, Cases C-293/13 P and C-294/13 P Fresh Del Monte Produce v European Commission, ECLI:EU:C:2015:416, para. 202.

53 Judgment of 16 January 2016, Case C-603/13 P Galp Energia Espana v European Commission, ECLI:EU:C:2016:38 para. 71; order of 7 July 2016, Case C-523/15 P Wesfälische Drahindustrie v European Commission, ECLI:EU:C:2016:541, para. 30; judgment of 15 December 2016, Case T-762/14 Philips and Philips France v European Commission, ECLI:EU:T:2016:738, para. 319 .

54 Judgment of 8 February 2007, Case C-3/06 P Group Danone v European Commission, ECLI:EU:C:2007:88, paras. 61-62; Case C-389/10 P KME Germany v European Commission, para. 130; judgment of 10 July 2014, Case C-295/12 P Telefonica et Telefonica de España, ECLI:EU:C:2014:2062, para. 198; judgment of 18 December 2014, Case C-434/13 P Commission v Parker Hannifin Manufacturing et Parker-Hannifin, ECLI:EU:C:2014:2456, para. 74; Case C-603/13 P Galp Energia Espana v European Commission, ECLI:EU:C:2016:38, para. 88.

55 Jugdment of 30 May 2013, Case C-70/12 P Quinn Barlo v European Commission, ECLI:EU:C:2013:351, para. 52;

56 C-434/13 P Commission v Parker Hannifin Manufacturing and Parker-Hannifin, ECLI:EU:C:2014:2456, para. 76; judgment of 26 January 2017, Case C-626/13 P Villeroy \& 
The other important issue is a question of what should initialise the control. Should this type of unlimited control towards a sanction only be used in cases where there is an error as to the legality of the decision in question that leads to an annulment? Is any error (including a minor error, not leading to an annulment) to be taken into account? Or perhaps nothing in terms of error is necessary, but the only issue that counts is the judge's (or court's) opinion ${ }^{57}$. In other words, it has to be examined, if the court needs a special justification to exercise this type of control. It seems that all the above scenarios might initiate the exercise of unlimited jurisdiction, but it is not necessarily the case. For instance, in the judgment Orange Polska, mitigating circumstances were not taken into account in order to reduce the fine, thus leaving the parties with the impression that the Court had not used its possibilities stemming from unlimited jurisdiction.

The other question is the scope of reforming powers as far as increase or decrease of the fine is concerned ${ }^{58}$.

If the Court considers decreasing the fine, should it indicate the reasons for it? Could it be only based on an error stated by that Court or might if also stem from an equality argument ${ }^{59}$ or a proportionality argument ${ }^{60}$. If the Court decides to increase the fine, it is confirmed by the jurisprudence that the General Court might vary the measure in question ${ }^{61}$. It can alter the amount of the fine ${ }^{62}$, both ex officio ${ }^{63}$ and following the suggestions of the Commission ${ }^{64}$. In the Galp Energia case, the Court of Justice found that the General Court exceeded the boundaries of its unlimited jurisdiction by taking into account

Boch Austria v European Commission, ECLI:EU:C:2017:54, para. 83; judgment of 26 September 2018, Case C-99/17 P Infineon Technologies AG v European Commission, ECLI:EU:C:2018:773, para. 194.

57 In judgment of 3 September 2009, Case C-534/07 P Prym et Prym Consumer v European Commission, ECLI:EU:C:2009:505 - the Court of Justice stated that unlimited jurisdiction allows the General Court to vary the contested measure, even without annulling it, by taking into account all of the factual circumstances, so as to amend, for example, the amount of the fine (para. 86). The judge can in fact determine the amount of the fine - it is not dependant of prior finding of illegality and may take into account elements which were not considered in the decision.

58 Case C-99/17 P Infineon Technologies AG v European Commission, para. 193; Case C-386/10 P Chalkor v European Commission, para. 63; C-626/13 P Villeroy \& Boch Austria $v$ European Commission, para. 81.

59 Order of 7 July 2016, Case C-523/15 P Westfällische Drahtindustrie, ECLI:EU:C:2016:541.

${ }^{60}$ Judgment of 17 December 2015, Case T-486/11 Orange Polska, ECLI:EU:T:2015:1002.

61 C-534/07 P Prym et Prym Consumer v European Commission.

62 Case C-295/12 P Telefonica et Telefonica de España.

63 Case T-348/94 Enso Espanola; C-3/06 P Groupe Danone v European Commission.

${ }^{64}$ Case T-69/04 Schunk GmbH and Schunk Kohlenstoff-Technik GmbH v European Commission. 
a plea raised on its own motion and by taking into account a statement of the director of sales of bitumen of Galp, which was not in the Commission's file but was produced later, only during the judicial procedure (Martinez-Lage, 2016, p. 609). The fact that the General Court found that the appellants could have been held liable under Article 101 TFEU for being aware of the participation of the other members of the cartel in the compensation mechanism, and were able to foresee their participation in the monitoring system (elements that were not established by the Commission in its investigation), and because of this adjusted the fine - were held by the Court of Justice as inadmissible. There is no need of prior finding of illegality - as the Court can also increase the fine. There is no doubt that such an increase can occur if it is an object of one of the pleas (one of the parties raises this problem) ${ }^{65}$. When a court is asked to reconsider the level of the fine (usually in order to reduce it) ${ }^{66}$, it examines the possibility of increasing the fine and the factors that might lead to it ${ }^{67}$ - the court, basing itself on Article 31 can increase the fine. This necessarily leads to the question if this, on its own, does not constitute an infringement of the prohibition of reformationis in peius. According to the Court of Justice, the fine can be increased, without infringing this principle ${ }^{68}$. The Court admits also that there is a general power of the Courts to change the level of fines ${ }^{69}$. However, this might happen if an important procedural guarantee had been fulfilled, namely, only if the parties have exercised their right to be heard, if there has been a plea concerning the level of fines ${ }^{70}$. There is no doubt that the fine can be increased if the Commission suggests it ${ }^{71}$. However, the Court is not able to fill all the possible gaps that have occurred during the proceedings in front of the Commission, as there is not transfer of competences in this field. There is also no doubt that the Court might benefit, even ex officio, one of the parties to the infringement (if reducing the fine for a daughter company, it also can reduce it for the mother company) by

65 Judgment of 29 March 2004, Cases T-236/01, T-239/01, T-244/01 to T-246/01, T-251/01 and T-252/01 Tokai Carbon v European Commission, ECLI:EU:T:2004:118, paras. 33, 95, 98, $112,272,286$.

66 Judgment of 25 October 2005, Case T-38/02 Groupe Danone v Commission, ECLI:EU:T:2005:367; Case C-3/06 P Group Danone v European Commission; judgment of 12 December 2007, Cases T-101/05, T-111/05 BASF v Commission, ECLI:EU:T:2007:380, para. 214.

67 Judgment of 8 July 2004, Cases T-67/00, T-68/00, T-71/00, T-78/00 JFE Engineering v European Commission, ECLI:EU:T:2004:221, paras. 578; judgment of 24 September 2009, Cases C-125/07 P, C-133/07P, C-135/07 P C-137/07 P Erste Group Bank v European Commission, ECLI:EU:C:2009:576, paras. 329-332.

68 Case C-534/07 Prym et Prym Consumer v European Commission.

69 Case C-295/12 P Telefonica et Telefonica de España.

70 Case C-125/07 P Erste Group Bank; Case C-3/06 P Groupe Danone v European Commission.

71 Case T-69/04 Schunk. 
reducing its fine ${ }^{72}$. But the opposite solution might raise issues of trespassing the principle of ne ultra petita ${ }^{73}$.

The Court usually and quite understandably takes a very 'cautious approach' to amending a fine using as the basis only the argument of its unlimited jurisdiction. When the Court is very restrictive in this area, it is in a sense not using the powers conferred on it. This cautionary approach is completely understandable taking into account all the existing jurisprudence that does not encourage the Court to step out of the limits of the plea. Still, it leaves an impression that the Court is not using all its powers given by unlimited jurisdiction.

\section{Functioning of control in case of unlimited jurisdiction}

The last issue that remains to be discussed is how to actually apply unlimited jurisdiction, namely how to readapt or recalculate the amount of fine, and is the Court actually prone and willing to do those operations? The imposition of the sanction (fine) lies at the heart of the Commission's appreciation of what it does as far as sanctions are concerned. There is no doubt that the Commission has a margin of discretion when imposing the fine ${ }^{74}$. The Commission decides on the level of fines and on the methodology to impose them. Usually, the General Court does not question the method or the general level of fines ${ }^{75}$. When fixing the fine, regard should be both to the gravity and to the duration of the infringement ${ }^{76}$ - this implies taking into account many factors that are controlled by the Court ${ }^{77}$, however no fully exhaustive list of factors to be taken into consideration exists ${ }^{78}$.

72 Judgment of 22 January 2013, Case C-286/11 P Commission v Tomkins, ECLI:EU:C:2013:29.

73 Judgment of 10 April 2014, Case C-231/11 P Siemens Österreich.

74 Judgment of 28 June 2005, C-189/02 P Dansk Rørindustrie, ECLI:EU:C:2005:408; judgment of 5 December 2013, Case C-447/11 P Caffaro, ECLI:EU:C:2013:797, para. 101.

75 Judgment of 15 July 2015, Case T-389/10 SLM, ECLI:EU:T:2015:513.

76 Case C-434/13 P Commission v Parker Hannifin Manufacturing et Parker-Hannifin, ECLI:EU:C:2014:2456, para. 75; Case C-626/13 P Villeroy \& Boch Austria v European Commission, para. 82; Case C-99/17 P Infineon Technologies AG v European Commission, para. 195; judgment of 11 July 2013, Case C-444/11 P Team Relocations e.a. v European Commission, ECLI:EU:C:2013:464, para. 10.

77 Jugment of 6 May 2009, Case T-127/04 KME Germany v European Commission, ECLI:EU:T:2009:142, paras. 94, 96-97. Of course, there might be an error as to the facts (f.i. value of sales).

78 Case C-99/17 P Infineon Technologies AG v European Commission, para. 198; Case C-534/07 P Prym et Prym Consumer v European Commission, para. 54, also judgment of 13 June 2013, Case C-511/11 P Versalis v European Commission, ECLI:EU:C:2013:386, para. 82. 
For years it has been common practice for the Court to simply check the application of the Commission Guidelines on the method of setting fines (hereinafter: Fining Guidelines) and not to proceed to any further analysis ${ }^{79}$. Usually the Court does not question the level of the fine or the method of imposing it ${ }^{80}$. There is usually little guidance in the legislation on the level of fines. Sometimes the Court does consider if the Commission should have analysed attenuating circumstances ${ }^{81}$. In the Intel case, there was an analysis of the possibility to apply the Fining Guidelines retroactively ${ }^{82}$. There is hardly any analysis of the purpose of the fine - be it deterrence, punishment, offence that is not profitable. In the Microsoft case, the potential dissuasive effect of the sanction has been analysed, but in a rather marginal manner.

The General Court is rarely also controlling the proportionality and appropriateness of fines. This does not exclude the possibility for the General Court to state such disproportionality ${ }^{83}$. In the case C-99/17 P, Infineon Technologies, the Court of Justice stated that it is not necessary to reduce the fine for each attenuating circumstance occurring in the case, but a general analysis leading to the assessment of the proportionality of the fine in question

79 Guidelines on the method of setting fines imposed pursuant to Article 23(2)(a) of Regulation No 1/2003, OJ C 210, 01.09.2006 (hereinafter: Fining Guidelines); Judgment of 15 July 2015, Case T-389/10 SLM, ECLI:EU:T:2015:513.

${ }^{80}$ Judgment of 15 July 2015, Case T-389/10 Siderurgica Latina Martin SpA (SLM) and Ori Martin SA v European Commission, ECLI:EU:T:2015:513.

81 Case C-447/11 P Caffaro, para. 104: 'C'est, dès lors, à bon droit que le Tribunal a jugé, au point 175 de l'arrêt attaqué, que, eu égard au niveau important de la réduction du montant de l'amende appliquée, dans le cadre de l'appréciation des circonstances atténuantes dans la décision litigieuse, au titre du rôle passif et mineur de Caffaro dans l'infraction, l'argumentation de cette société tirée de l'existence d'autres circonstances atténuantes, non admises par la Commission, même à la supposer fondée, n'était pas susceptible de conduire à admettre le caractère inadéquat d'une réduction, accordée par la Commission au titre de cette appréciation'. [There is no official English translation: It is, therefore, approriate that the Court has, in the point 175 of the judgment under appeal, judged that, taking into consideration the important level of the reduction of the fine applied, taking into account the attenuating circumstances indicated in the contested decision, the passive and minor role played by Caffaro in the infringement, arguments of this company as to the existence of other attenuating circumstances, not taken into account by the Commission, if they were to be found founded, it was not possible to admit the inadequate character of the reduction granted by the Commission in terms of this appreciation].

82 Retroactive application of theFining Guidelines is possible in accordance with Art. 7 and 49 of the Charter - judgment of 12 June 2015, Case T-286/09 Intel v European Commission, ECLI:EU:T:2014:547, paras. 1596-1598, confirmed on those points by judgment of 6 September 2017, Case C-413/14 P Intel Corp. v European Commission, ECLI:EU:C:2017:632.

83 Judgment of 15 July 2015, Case T-418/10 Voestalpine v European Commission, ECLI:EU:T:2015:516, para. 442. 
should always be done ${ }^{84}$. In this case also, the Court of Justice stated that the General Court has to, in order to fulfill its powers of unlimited jurisdiction, take into account a plea raised by the applicant as to the proportionality of the fine ${ }^{85}$. However, in this very case it admitted that this control of proportionality might be done with regard to the Fining Guidelines of the Commission only ${ }^{86}$.

In the case Kone, the question of the self-limitation of the Commission by its own Fining Guidelines, as to its margin of discretion, was broadly discussed ${ }^{87}$. If unlimited jurisdiction is exercise to recalculate the fine, it seems that the General Court, as in any other circumstances when it takes a decision, should state the grounds for both using unlimited jurisdiction and for explaining the way it was used. As to the 'pre-visibility' of the sanction, the Commission is free to change its practice according to the Court, as long as it explains it ${ }^{88}$.

When exercising unlimited jurisdiction, the Court cannot impose a new sanction. It has no power to impose a fine - just a review on fines imposed by the Commission's decision. The Court has also a duty to motivate its decision to change the fine. It is clear that the Commission's Fining Guidelines are not binding on the Court, however it seems that the Court is in principle almost always simply following them. The Court seems reluctant to reduce fines - except for the situation where the Commission has committed an error: 1) not proving the infringement to the full extend found by the decision, 2) not taking into account certain elements in the setting of the fine, 3) some defect in the reasoning of the Commission's decision, which is not sufficient to justify a complete annulment. Usually, if the Court finds no error, it does not amend the fine. It is rare that the fine is found excessive and thus - reduced ${ }^{89}$. An increase of the fine is even rarer, barely non-existent. The main reasons for this is that it would normally be considered as adjudicating ultra petita and against adversarial proceedings. Nevertheless, if the Court states the case of

84 Case C-99/17 P Infineon Technologies AG v European Commission, para. 212.

85 Case C-99/17 P Infineon Technologies AG v European Commission, para. 206.

86 Case C-99/17 P Infineon Technologies AG v European Commission, para. 210, cf also: judgment of 26 January 2017, Case C-604/13 P Aloys F. Dornbracht v European Commission, ECLI:EU:C:2017:45, para. 75; judgment of 16 June 2011, Case T-211/08 Putters International, ECLI:EU:T:2011:289.

${ }^{87}$ But it was stated that the possible misapplication of the Fining Guidelines is not a question of public order - cf judgment of 24 October 2013, Case C-510/11 P Kone e.a. v European Commission, ECLIEU:C:2013:696, paras. 70-72.

88 Judgment of 7 June 1983, Cases 100-103/80 Pioneer, ECLI:EU:C:1983:158; judgment of 28 June 2005, Case C-189/02 P Dansk Rørindustrie, ECLI:EU:C:2005:408.

89 Judgment of 13 December 2006, Cases T-217/03 and T-245/03 Fédération nationale de la coopération bétail et viande (FNCBV) and Fédération nationale des syndicats d'exploitants agricoles (FNSEA) and Others v European Commission, ECLI:EU:T:2006:391, in the judgment of 17 December 2015, Case T-486/11 Orange Polska, ECLI:EU:T:2015:1002 - the General Court on its own reassessed the fine once the legality of the decision was examined. 
either - repetition of infringement, refusal to cooperate, or role of leader or instigator, it takes it into account ${ }^{90}$.

\section{Conclusions}

It is difficult to be exhaustive about unlimited jurisdiction. The scope of judicial control in the European Union is an ever-open subject. The three questions analysed in this text reveal clearly that the notion of 'limitlessness' is posing some problems and its content is prone to be differently interpreted. As to the exact scope of the notion of unlimited jurisdiction, its intensity and the actual functioning of judicial control in case of unlimited jurisdiction, the jurisprudence presented in this article reveals rather limiting tendencies in interpretation. So while it is very tempting to broaden the scope of judicial control, the General Court is bound not to act ultra petita or to raise some issues on its own motion if they are not covered by public order measures (like the questions of admissibility or motivation). The General Court has neither a competence to reform decisions of the European Commission nor to lead its own investigation to gather new proofs in the matter in question. Despite, or even because of, all those limitations, the pattern of judicial review exercised by the General Court remains an ever-developing subject.

\section{Literature}

Arabardijev, A. (2012). Unlimited jurisdiction: what does it mean today? In: P. Cardonnel, A. Rosas, N. Wahl (eds.), Constitutionalising the EU judicial system: essays in honour of Pernilla Lindh, Hart Publishing, https://doi.org/10.5040/9781472566140.ch-025.

Bernardeau, L., Christienne, J.-P. (2013). Les amendes en droit de la concurrence. Pratique décisionnelle et contrôle juridictionnel du droit de l'Union. Brussels: Larcier.

Bombois, T. (2011). Larrêt Menarini c. Italie de la Cour européenne des droits de l'homme: droit antitrust, champ pénal et contrôle de pleine juridiction. Cahiers de droit européen, 2, 541-589

Bosco, D. (2014). La compétence de pleine jurisdiction du juge de l'Union quant aux amendes prononcées par la Commission européenne en matière de concurrence. In: S. Mahieu (ed.), Contentieux de l'Union européenne: questions choisies. Brussels: Larcier

Castillo de la Torre, F., Gippini Fournier, E. (2017). Evidence, Proof and Judicial Review in EU Competition Law. Edward Elgar; https://doi.org/10.4337/9781782548904.

90 Para. 28 of the Fining Guidelines, p. 2-5. 
Chapus, R. (2006). Droit du contentieux administratif. Paris: Montchrestien.

Clausen, F. (2018). Les moyens d'ordre public devant la Cour de justice de l'Union européenne. Bruxelles:Bruylant.

Craig, P. (2012). EU Administrative Law. Oxford: Oxford University Press.

Expert, H., Poullet, C. (2017). La compétence de pleine juridiction conférée au juge de l'Union en matière de concurrence : complément ou accessoire du contrôle de légalité? In: V. Giacobbo-Peyronnel, C. Verdure (eds.), Contentieux du droit de la concurrence de l'Union européenne. Questions d'actualité et perspectives. Bruxelles: Bruylant.

Giacobbo-Peyronnel, V., Perillo, E. (eds.) (2017). Statut de la fonction publique de l'Union européenne. Commentaire article par article. Bruxelles: Bruylant.

Jaeger, M. (2011). Standard of Review in Competition Cases: Can the General Court Increase Coherence in the European Union Judicial System? In: T. Baumé, E. Oude Elferin, P. Phoa, D. Thiaville (eds.), Today's Multilayered Legal Order: Current issues and Perspectives: Liber Amicorum in Honour of Arjen WH. Meij. Paris: Uitgeverij Paris B.V.

Martinez-Lage, P. (2016). Galp Energia España : Limitations on the General Court's Unlimited Jurisdiction to Review Decisions Imposing Fines. Journal of European Competition Law \& Practice, 7, 9, 608-610; https://doi.org/10.1093/jeclap/lpw023.

Nikolic, I. (2012). Full Judicial Review of Antitrust Cases after KME: A New Formula of Review? European Competition Law Review, 12, 583-588.Vesterdorf, B. (2009). The Court of Justice and unlimited jurisdiction: what does it mean in practice? The Online Magazine for Global Competition Policy. Retrieved from: https://www. competitionpolicyinternational.com/assets/0d358061e11f2708ad9d62634c6c40ad/ Vesterdorf-JUNE-09_2_.pdf (22.10.2019).

Wahl, N. (2015). Enjeu et limites actuelles de la jurisprudence relative à la compétence de pleine juridiction conférée au juge de l'Union en matière de concurrence. In: A. Tizzano (ed.), La Cour de justice de l'Union européenne sous la présidence de Vassilios Scouris (2003-2015). Liber amicorum Vassilios Skouris. Bruxelles: Bruylant. 